\title{
Characterization of HCV Genotype 5a Envelope Proteins: Implications for Vaccine Development and Therapeutic Entry Target
}

\author{
Maemu Petronella Gededzha ${ }^{1, *}$; Maphahlanganye Jeffrey Mphahlele ${ }^{1}$; Selokela Gloria \\ Selabe ${ }^{1}$ \\ ${ }^{1}$ Department of Virology, HIV and Hepatitis Research Unit, University of Limpopo, Medunsa Campus/National Health Laboratory Service, Pretoria, South Africa \\ *Corresponding Author: Maemu Petronella Gededzha, Department of Virology, HIV and Hepatitis Research Unit, University of Limpopo, Medunsa Campus/National Health Labora- \\ tory Service, Pretoria, South Africa. Tel: +27-125213631, Fax: +27-125215794, E-mail: maemup@yahoo.com
}

Received: September 15, 2014; Revised: October 8, 2014; Accepted: October 26, 2014

\begin{abstract}
Background: Hepatitis C virus (HCV) is one of the major causes of cirrhosis and hepatocellular carcinoma with an estimation of 185 million people with infection. The E2 is the main target for neutralizing antibody responses and the variation of this region is related to maintenance of persistent infection by emerging escape variants and subsequent development of chronic infection. While both E1 and E2 are hypervariable in nature, it is difficult to design vaccines or therapeutic drugs against them.

Objectives: The objective of this study was to characterize genotype $5 \mathrm{a}$ E1 and E2 sequences to determine possible glycosylation sites, conserved B-cell epitopes and peptides in HCV that could be useful targets in design of vaccine and entry inhibitors.

Patients and Methods: This study was conducted through PCR amplification of E1 and E2 regions, sequencing, prediction of B-cell epitopes, analysis of N-linked glycosylation and peptide design in 18 samples of HCV genotype 5a from South African.

Results: Differences in the probability of glycosylation in E1 and E2 regions were observed in this study. Three conserved antigenic B-cell epitopes were predicted in the $\mathrm{E} 2$ regions and also 11 short peptides were designed from the highly conserved residues.

Conclusions: This study provided conserved B-cell epitopes and peptides that can be useful for designing entry inhibitors and vaccines able to cover a global population, especially where genotype 5 a is common.
\end{abstract}

Keywords: Hepatitis C Virus; Genotype; Epitopes; Peptides

\section{Background}

Globally, an estimated 185 million people have been infected with hepatitis $\mathrm{C}$ virus (HCV) as one of the major causes of cirrhosis and hepatocellular carcinoma (1). HCV genome consists of approximately 9.6 kilobases, positive-sense single-stranded RNA, which encodes three structural (C, E1 and E2) and 7 non-structural (p7, NS2, NS3, NS4A, NS4B, NS5A and NS5B) proteins flanked by 5' and 3' untranslated regions (UTR) (2). E1 and E2 proteins are type I transmembrane proteins with both N-terminal ectodomain and a C-terminal domain (3) and contain 6 and 11 glycosylation sites, respectively $(4,5)$. These proteins are involved in viral entry by interacting with CD81 and Scavenger receptor class B member 1 (SRB1) (6-8). HCV glycosylation sites play an essential role in envelope proteins to ensure correct conformation for virus entry $(5,9)$ and antigenic variation (10). HCV E2 glycosylation sites interact with cell surface receptors directly allowing the virus to enter the cell $(11,12)$. Glycosylation sites may mask important epitopes from host antibody responses $(13,14)$. B-cell epitopes are essential in increasing the preferred immune responses $(15,16)$ and number of epitopes and modulation of immune recognition of antigens can be influenced by deglycosylation of E1 proteins (17). The
E1 derived peptide p35 (amino acid (aa) 315-323) (18), E2conserved synthetic peptides p37 (aa 517-531) and p38 (aa 412-419) have been reported to neutralize HCV particles, as important components of a candidate peptide vaccine (19). The molecular targets for current HCV Direct-acting antiviral (DAA) in development are mainly focused on non-structural proteins such as the NS3 protease, NS5A and the NS5B RdRp (20). Recently, considerable progress has been made to understand HCV entry $(21,22)$ and development of entry inhibitors $(20,21,23,24)$. Many patients do not respond to the current available therapy, therefore, there is an urgent need to develop effective $\mathrm{HCV}$ vaccines and specific therapeutic drugs. While both E1 and E2 are hypervariable in nature, it is difficult to design vaccines or therapeutic drugs against them. Genotype 5 a accounts for over $50 \%$ of HCV infections in South Africa (25).

\section{Objectives}

This study aimed to characterize genotype 5a E1 and E2 sequences to determine possible glycosylation sites, conserved B-cell epitopes and peptides in HCV that could be useful targets in the design of vaccine and entry inhibitors.

Copyright (C) 2014, Kowsar Corp. This is an open-access article distributed under the terms of the Creative Commons Attribution-NonCommercial 4.0 International License (http://creativecommons.org/licenses/by-nc/4.0/) which permits copy and redistribute the material just in noncommercial usages, provided the original work is properly cited. 


\section{Patients and Methods}

\subsection{Study Population}

This study included 18 genotype 5a samples collected from treatment-naive HCV infected patients at Dr. George Mukhari Academic Hospital (DGMAH), north-west of Pretoria, South Africa, from 2007 to 2011. Patients' demographics and genotyping based on 5'UTR were previously described in detail (25). Six of 18 samples were sequenced as part of the genotype 5a near-full length analysis previously described (26). DGMAH is an academic hospital serving a population of around 4 million from both rural and urban areas. It is a referral hospital for patients from the North West, Mpumalanga, Limpopo and the northwest part of Pretoria, Gauteng. The Medunsa Research and Ethics Committee approved the study.

\subsection{PCR and Sequencing}

Viral RNA was extracted from $140 \mu \mathrm{L}$ of serum using the QIAamp Viral RNA Mini Kit (Qiagen, Hilden, Germany) according to the manufacturer's instructions. HCV RNA was converted into cDNA using the enzyme RevertAid TM RT-PCR (Fermentas, Vilnius, Lithuiana). The cDNA was amplified in three overlapping fragments (Table 1) covering complete E1 and E2 regions. Direct sequencing was performed with ABI 3500XL (Inqaba Biotechnological Industry, PTY, Ltd, Pretoria, South Africa) using second round PCR primers. Sequence fragment assembly was performed using Chromas Pro1.5 (www.technelysium. com.au/chromas.html). All sequences were aligned by Mafft (mafft.cbrc.jp/alignment/server/) and translated into amino acids using BioEdit (27).

\subsection{Analysis of N-Linked Glycosylation Sites}

The N glycosylation sites were predicted using the online prediction server NetNGlyc version 1.0 (http://www. cbs.dtu.dk/services/NetNGlyc/), which predicts $\mathrm{N}$ glycosylation sites in proteins by artificial neural networks that examine the sequence context of Asn-Xaa-Ser/Thr sequins. The networks can identify $86 \%$ of the glycosylated and $61 \%$ of the non-glycosylated sequins, with an overall accuracy of $76 \%$.

\subsection{Prediction of B-Cell Epitopes}

For identification of B-cell epitopes, 16-mer B-cell epitopes was predicted using the program ABCpred (http:// www.imtech.res.in/raghava/abcpred/) at a 0.51 default threshold using a consensus sequence from 18 genotype 5a sequences created using Bioedit. ABCpred server predicts B-cell epitopes using artificial neural network using fixed length patterns (28). Antigenicity of all predicted epitopes was analyzed using Vaxijen v2.0 online antigen prediction (www.ddg-pharmfac.net/vaxijen/). Proteins having antigenic score more than 0.4 were selected as antigenic. Vaxijen v2.0 allows antigen classifi- cation based on physicochemical properties of proteins without recourse to sequence alignment. All predicted epitopes were analyzed for conservation using the IEDB database (http://tools.immuneepitope.org/tools/conservancy/iedb_input) at a threshold of $100 \%$ conservation compared to $406,221,98,33,45,45$ randomly selected sequences from each of the HCV genotypes 1a, 1b, 2, 3, 4 and 6 , respectively.

\subsection{Peptide Design}

Structure analysis of sequence was performed using the Protparam online tool (29). Protparam computed different parameters including the molecular weight, theoretical pI, AA composition, atomic composition, extinction coefficient, instability index, aliphatic index and grand average of hydropathicity (GRAVY). To check post-translational modifications, predicted peptides were predicted for N-linked glycosylation as described above and for $\mathrm{N}$ linked phosphorylation using the NetPhos 2.0 (30) program. The NetPhos 2.0 produces neural network predictions for serine, threonine and tyrosine phosphorylation sites in sequences. Only those motifs with NetPhos score of 0.7 or greater were considered.

\subsection{GenBank Accession Numbers}

Sequences were submitted to GenBank under the accession numbers KC7678835 - KC767846.

Table 1. Sequences of the HCV Primers Used in This Study

\begin{tabular}{|c|c|c|c|}
\hline Sequences & & Primers & Reference \\
\hline $\mathbf{A}$ & & & this study \\
\hline F1A & 1088 & $\begin{array}{l}\text { GAC CAT TTC ATC ATC ATG TCC } \\
\text { CA }\end{array}$ & \\
\hline R1A & 1425 & $\begin{array}{l}\text { TGT ATG CGG CGG CGA ACA } \\
\text { AGA CC }\end{array}$ & \\
\hline $\mathrm{F} 2 \mathrm{~A}$ & 1113 & $\begin{array}{c}\text { CTT CGG AGG GCC GTT GAC TAC } \\
\text { TTA GCG }\end{array}$ & \\
\hline $\mathrm{R} 2 \mathrm{~A}$ & 1413 & $\begin{array}{c}\text { CGA ACA AGA CCC CCC AGT } \\
\text { GGG }\end{array}$ & \\
\hline \multicolumn{4}{|l|}{ B } \\
\hline M105 & 1292 & ATG GCA TGG GAC ATG ATG ATG & (27) \\
\hline R1B & 2061 & $\begin{array}{l}\text { TAG GCC CTA AGT TGC AGG } \\
\text { GTG GA }\end{array}$ & this study \\
\hline M106 & 1298 & TGG GAC ATG ATG ATG AAT TGG & $(27)$ \\
\hline $\mathrm{R} 2 \mathrm{~B}$ & 2022 & $\begin{array}{c}\text { CAA ACC CTG TGG AAT TCA TCC } \\
\text { AG }\end{array}$ & this study \\
\hline C & & & this study \\
\hline $\mathrm{F} 1 \mathrm{C}$ & 1743 & GGC TGG GGA ACT ATC AGC TAT & \\
\hline $\mathrm{R} 1 \mathrm{C}$ & 2636 & $\begin{array}{c}\text { AAA CCC ATG AGT CCC CGC } \\
\text { AGC C }\end{array}$ & \\
\hline $\mathrm{F} 2 \mathrm{C}$ & 1773 & TCG GGC CCC AGT GAT GAC AAG & \\
\hline $\mathrm{R} 2 \mathrm{C}$ & 2612 & $\begin{array}{c}\text { AGC CGC GTT TAG GAC AAT GAC } \\
\text { GTT CT }\end{array}$ & \\
\hline
\end{tabular}


Gededzha MP et al.

\section{Results}

\subsection{Sequence Alignment and Genetic Distances}

Sequence alignment of 18 genotype 5a sequences with a reference sequence from the GenBank showed that most regions in the genotype $5 \mathrm{a}$ E1 and E2 proteins were conserved except hypervariable 1 (HVR1), which was highly variable as expected. Comparison of genetic distances between sequences in this study showed intragroup genetic distances ranging from $8 \%$ to $17 \%$, with an average distance of $13 \%$ (Table 2 ).

\subsection{Analysis of E1 and E2 N-Linked Glycosylation}

E1 and E2 proteins of 18 sequences were analyzed for possible glycosylation sites. Differences in the probability of glycosylation in E1 and E2 were observed in most sequences. Whereas other studies reported five N-linked glycosylation sites in the E1 region, all strains in the current study showed three or four glycosylation sites, except for ZADGM2088, which showed 2 glycosylation sites, with N325 site not predicted as glycosylation sites from all sequences. In the E2 region, three sequences (ZADGM1104, ZADGM1707 and ZADGM3013) showed nine glycosylation sites, while the remaining had variations in the number of glycosylation sites. In ZADGM308, position N430 was replaced by $\mathrm{H}$, while in ZADGM6544, N448 was replaced by D. Site N476 was found in only 6 of analyzed 18 sequences. The E2 sites N423 and N576 were not predicted as glycosylation sites in all genotype 5 a sequences in this study (Table 3).

\subsection{B-Cell Epitopes Prediction}

Three conserved antigenic B-cell epitopes were predicted for genotype 5a sequences in the E2 region. Epitope E2 ${ }^{504-609}$ (GPVYCFTPSPVVVGTT) had the highest antigenic score of 1.1613 , while E2 ${ }^{675-690}$ (LPCSFTPTPALSTGLI) and E2 ${ }^{685-700}$ (LSTGLIHLHQNIVDTQ) had antigenic scores of 0.5340 and 0.6639 , respectively. For conservancy analysis, epitope $\mathrm{E}^{2504-609}$ was highly conserved among other genotypes, while epitope $\mathrm{E}^{2675-690}$ and $\mathrm{E}^{2685-700}$ were variable (Table 4).

Table 2. Genetic Distances in E1 and E2 Sequences of Genotype 5a in This Study

\begin{tabular}{|c|c|c|c|c|c|c|c|c|c|c|c|c|c|c|c|c|c|c|c|}
\hline & & \multicolumn{18}{|c|}{ Genetic Distances a, b } \\
\hline & Sequence & 1 & 2 & 3 & 4 & 5 & 6 & 7 & 8 & 9 & 10 & 11 & 12 & 13 & 14 & 15 & 16 & 17 & 18 \\
\hline 1 & ZADGM7890 & & & & & & & & & & & & & & & & & & \\
\hline 2 & ZADGM6544 & 0.12 & & & & & & & & & & & & & & & & & \\
\hline 3 & ZADGM4227 & 0.13 & 0.12 & & & & & & & & & & & & & & & & \\
\hline 4 & ZADGM1908 & 0.14 & 0.12 & 0.13 & & & & & & & & & & & & & & & \\
\hline 5 & ZADGM1707 & 0.10 & 0.12 & 0.11 & 0.12 & & & & & & & & & & & & & & \\
\hline 6 & ZADGM651 & 0.13 & 0.13 & 0.14 & 0.13 & 0.12 & & & & & & & & & & & & & \\
\hline 7 & ZADGM308 & 0.12 & 0.12 & 0.12 & 0.12 & 0.10 & 0.11 & & & & & & & & & & & & \\
\hline 8 & ZADGM6485 & 0.13 & 0.10 & 0.13 & 0.12 & 0.12 & 0.12 & 0.10 & & & & & & & & & & & \\
\hline 9 & ZADGM4124 & 0.13 & 0.13 & 0.13 & 0.13 & 0.12 & 0.14 & 0.13 & 0.12 & & & & & & & & & & \\
\hline 10 & ZADGM2439 & 0.14 & 0.15 & 0.15 & 0.15 & 0.12 & 0.14 & 0.12 & 0.13 & 0.14 & & & & & & & & & \\
\hline 11 & ZADGM2352 & 0.13 & 0.14 & 0.14 & 0.14 & 0.13 & 0.12 & 0.11 & 0.12 & 0.14 & 0.13 & & & & & & & & \\
\hline 12 & ZADGM525gp & 0.14 & 0.14 & 0.15 & 0.14 & 0.12 & 0.15 & 0.14 & 0.14 & 0.14 & 0.16 & 0.16 & & & & & & & \\
\hline 13 & ZADGM869 & 0.14 & 0.14 & 0.15 & 0.13 & 0.13 & 0.10 & 0.13 & 0.13 & 0.14 & 0.14 & 0.14 & 0.17 & & & & & & \\
\hline 14 & ZADGM3013 & 0.15 & 0.14 & 0.14 & 0.15 & 0.12 & 0.15 & 0.13 & 0.12 & 0.15 & 0.15 & 0.15 & 0.17 & 0.15 & & & & & \\
\hline 15 & ZADGM0518 & 0.9 & 0.12 & 0.11 & 0.12 & 0.08 & 0.13 & 0.10 & 0.11 & 0.11 & 0.12 & 0.13 & 0.14 & 0.13 & 0.11 & & & & \\
\hline 16 & ZADGM2582 & 0.14 & 0.14 & 0.13 & 0.14 & 0.13 & 0.13 & 0.12 & 0.13 & 0.14 & 0.13 & 0.13 & 0.16 & 0.15 & 0.15 & 0.13 & & & \\
\hline 17 & ZADGM2088 & 0.14 & 0.13 & 0.13 & 0.13 & 0.12 & 0.12 & 0.11 & 0.12 & 0.13 & 0.14 & 0.12 & 0.13 & 0.14 & 0.14 & 0.12 & 0.12 & & \\
\hline 18 & ZADGM1104 & 0.13 & 0.14 & 0.13 & 0.14 & 0.12 & 0.13 & 0.09 & 0.12 & 0.14 & 0.14 & 0.14 & 0.13 & 0.15 & 0.15 & 0.12 & 0.14 & 0.13 & \\
\hline
\end{tabular}

\footnotetext{
${ }^{\mathrm{a}}$ The values range between $0(0 \%)$ and $1(100 \%)$ substitutions per nucleotide site.
}

$\mathrm{b}$ The numbers 1-18 corresponds to the sequence number on the vertical side. 
Gededzha MP et al.

Table 3. Probability of Glycosylation in E1 and E2 Sequences

Probability at Glycosylation Site ${ }^{\mathrm{a}, \mathrm{b}}$

\begin{tabular}{|c|c|c|c|c|c|c|c|c|c|c|c|c|c|c|c|c|c|}
\hline \multirow{2}{*}{\multicolumn{2}{|c|}{ Sequence }} & \multicolumn{5}{|c|}{ E1 } & \multirow[t]{2}{*}{ No of Sites } & \multicolumn{9}{|c|}{ E2 } & \multirow[t]{2}{*}{ No of Sites } \\
\hline & & 196 & 209 & 234 & 305 & 325 & & 417 & 430 & 448 & 476 & 533 & 541 & 557 & 623 & 645 & \\
\hline 1 & ZADGM7890 & + & ++ & ++ & + & - & 4 & + & ++ & - & - & + & ++ & + & + & + & 7 \\
\hline 2 & ZADGM6544 & + & ++ & + & - & - & 3 & + & ++ & - & - & - & ++ & + & + & + & 6 \\
\hline 3 & ZADGM4227 & + & ++ & ++ & + & - & 4 & ++ & ++ & - & - & + & - & + & + & + & 6 \\
\hline 4 & ZADGM1908 & + & ++ & + & - & - & 3 & ++ & + & - & + & ++ & + & + & + & - & 7 \\
\hline 5 & ZADGM1707 & + & ++ & + & + & - & 4 & ++ & + & + & + & + & ++ & + & + & + & 9 \\
\hline 6 & ZADGM651 & + & ++ & ++ & + & - & 4 & ++ & + & - & - & + & + & + & + & - & 6 \\
\hline 7 & ZADGM308 & + & ++ & ++ & - & - & 3 & ++ & - & + & - & + & ++ & + & + & - & 6 \\
\hline 8 & ZADGM6485 & + & ++ & ++ & - & - & 3 & ++ & ++ & - & + & + & ++ & + & + & - & 7 \\
\hline 9 & ZADGM4124 & + & ++ & + & + & - & 4 & ++ & + & - & - & + & + & + & + & + & 7 \\
\hline 10 & ZADGM2439 & + & ++ & + & + & - & 4 & ++ & + & - & + & + & + & + & + & - & 7 \\
\hline 11 & ZADGM2352 & + & ++ & ++ & - & - & 3 & ++ & ++ & - & - & + & ++ & + & + & - & 6 \\
\hline 12 & ZADGM525gp & - & ++ & ++ & + & - & 3 & ++ & + & - & - & - & + & + & + & + & 6 \\
\hline 13 & ZADGM869 & + & ++ & + & - & - & 3 & + & ++ & - & - & + & + & + & + & + & 7 \\
\hline 14 & ZADGM3013 & + & ++ & + & + & - & 4 & ++ & ++ & + & + & + & ++ & + & + & + & 9 \\
\hline 15 & ZADGM0518 & + & ++ & + & - & - & 3 & ++ & ++ & ++ & - & - & ++ & + & + & - & 6 \\
\hline 16 & ZADGM2582 & + & ++ & + & - & - & 3 & ++ & + & - & + & + & ++ & + & + & + & 8 \\
\hline 17 & ZADGM2088 & - & ++ & ++ & - & - & 2 & ++ & + & - & - & + & + & + & + & - & 6 \\
\hline 18 & ZADGM1104 & + & ++ & ++ & - & - & 3 & ++ & ++ & + & + & + & + & + & + & + & 9 \\
\hline
\end{tabular}

Table 4. Predicted B-Cell Epitopes of HCV Genotype 5a and Their Antigenicity Score, Number of Allele and Conservancy (Percentage) in Different Genotypes

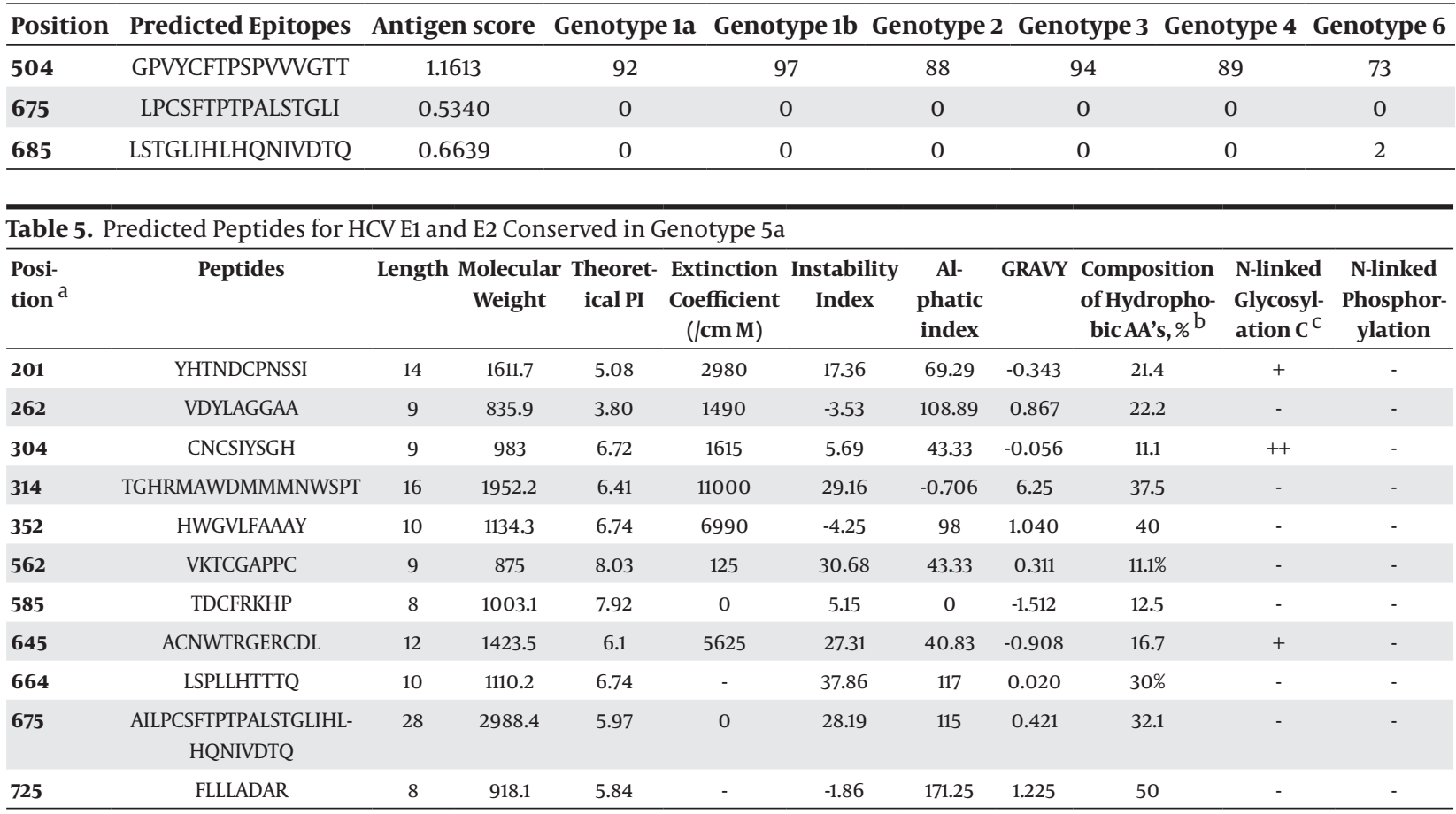

a Numbering is based on the M62321 full-length sequence.

$\mathrm{b}$ list of hydrophobic amino acids (Leu, Val, Ile, Met, Phe and Trp).

c Glycosylation probability is shown by +++ (probability $>70 \%),++$ (probability between 60 and $70 \%$ ), + (probability between 50 and $60 \%)$, and - (not present). 
Gededzha MP et al.

\subsection{Peptide Design}

From the consensus sequences of genotype 5a E1 and E2, eleven short peptides of 8-28 amino acids were designed from the highly conserved residues. Five peptides of 9-16 amino acids in length were derived in the E1 region, while six peptides of 8-26 amino acids were derived in the E2. Three of the peptides had post-translation modification, which is the N-linked glycosylation, although at a low probability. None of the peptides has either serine, threonine and tyrosine phosphorylation sites predicted. Most peptides were found to be the best predicted peptides useful for designing entry inhibitors (Table 5).

\section{Discussion}

Genotype 5 is the most conserved HCV genotype classified into only one subtype (5a) (26). This study was designed to identify conserved sequences of these proteins to predict antigenic epitopes and peptides that could serve as best targets for vaccine design and potential entry inhibitors. Using different structural and sequence analyses tools helped with in-silico analysis for E1 and E2 regions. HCV genotype 5a sequences were found to be conserved in most regions of E1 and E2 proteins. The most variable region within the study sequences was the HVR1 and these HVR1 differed by up to $80 \%$ between HCV genotypes and subtypes (31). Although highly variable, the HVR1 is the only region that contains neutralization determinant, which is the target for immune response (32). As expected due to HVR variability, comparison of genetic distances between sequences in this study showed high genetic distances ranging from $8 \%$ to $17 \%$, with an average distance of $13 \%$. Variability within the HVR1 is one of the reasons describing why human antibodies raised against HCV E2 epitopes do not provide protection against multiple viral infections (19). In this study, analysis of N-linked glycosylation sites revealed that genotype 5a sequences were not conserved at glycosylation sites as compared to other genotypes. Site N476 with a level of 75\% conservation among different genotypes was absent from the sequences of genotype $5 \mathrm{a}$ (5) and was found in six of the 18 analyzed sequences. As reported previously, E2 sites N423 and N576 were absent in all genotype 5a sequences including the 18 sequences from this study, which is notable because these two sites were reported to be $99-100 \%$ conserved across all genotypes (5). The glycosylation sites were reported to be highly conserved among different genotypes (9). These sequence variations in genotype $5 a$ glycosylation sites could be useful to design efficient vaccine to help host to produce good antibody response. E2 is the main target for neutralizing antibody responses and variation of this region is thought to be related to maintenance of persistent infection by emerging escape variants and subsequent development of chronic infection $(33,34)$. Recently, a linear region of E2 encompassing amino acids 434 to 446 has been reported to elicit nonneutralizing antibodies that can inhibit neutralizing ac- tivity of antibodies targeting amino acids 412 to 423 (35). However, a study by Tarr et al. reported conflicting results showing that human antibodies that target the region encompassing amino acids 434 to 446 , are not inhibitory but capable of neutralizing HCVpp and HCVcc entry (36). All B-cell epitopes included in this study were found to be antigenic ally effective, and it can be implied that these epitopes may be important for inducing the desired immune response. The E $^{2504-609}$ epitope was found to be the most conserved among other genotypes. Recently a study by Ikram et al. reported conserved epitopes among genotype $3 \mathrm{a}$ that was also conserved among other genotypes (37). Highly conserved epitopes might influence the immunogenic potential since variability within the epitopes can increase the chance of immune escape (38). Short polypeptides derived from viral envelope sequences of other viruses have been used to investigate protein interactions involved in viral entry and some antiviral agents have been successfully developed (39). Envelope protein peptide inhibitors for other viruses in the same family with HCV like Dengue and West Nile were shown to inhibit viral entry $(40,41)$. In HCV, the post-binding entry step was prevented using peptides derived from the $C$ terminal region of $\mathrm{E} 2$, which plays an important role in the HCV entry process (42). For this study, conserved peptides were derived that can be used as targets for therapeutic purposes. In this study, only three peptides had glycosylation sites at low probability and no phosphorylation sites were predicted. Post translational modifications such as glycosylation and phosphorylation affect the stability of therapeutic peptides (43). Using HCV glycoproteins in therapeutic strategies may offer protection against HCV infection (44). In conclusion, genotype 5a sequences are conserved and can be used to design epitopes and peptides. The results showed that antigenic conserved predicted B-cell epitopes and stable peptides with few post-translational modifications. These epitopes and peptides are potential candidates to design entry inhibitors and vaccines able to cover a global population, especially where genotype $5 \mathrm{a}$ is common. Further investigations would analyze these peptides to better understand their involvement in blocking HCV entry.

\section{Acknowledgements}

We would like to acknowledge all members of the HIV and Hepatitis Research Unit, Department of Virology, Pretoria, South Africa for their technical help and writing assistance.

\section{Authors' Contributions}

Maemu Petronella Gededzha designed the study, performed lab work, analyzed data and drafted the manuscript. Selokela Gloria Selabe and Maphahlanganye Jeffrey Mphahlele supervised the project and critically reviewed the manuscript. All authors read and approved the final manuscript. 


\section{Funding/Support}

This work was supported by grants from Medical Research Council, National Research Foundation, National Health Laboratory Service Research Trust, and The Stella \& Paul Loewestein Charitable and Educational Trust in South Africa.

\section{References}

1. World health Organization.. Guidelines for the screening care and treatment of persons with hepatitis C infection.: WHO; 2014. Available from: http://www.who.int/hiv/pub/hepatitis/hepatitis-cguidelines/en/.

2. Lemon SM, Walker C, Alter MJ, Yi M. Hepatitis C virus. In: Knipe DM, Howley PM editors. Fields Virology:: Lippincott Williams and Wilkins; 2007. pp.1253-304.

3. Chevaliez S, Pawlotsky JM. HCV Genome and Life Cycle. In: Tan SL editor. Hepatitis CViruses: Genomes and MolecularBiology.. Norfolk UK: Horizon Bioscience; 2006. pp. 45-7.

4. Drummer HE, Maerz A, Poumbourios P. Cell surface expression of functional hepatitis C virus E1 and E2 glycoproteins. FEBS Lett. 2003;546(2-3):385-90.

5. Goffard A, Dubuisson J. Glycosylation of hepatitis C virus envelope proteins. Biochimie. 2003;85(3-4):295-301.

6. Higginbottom A, Quinn ER, Kuo CC, Flint M, Wilson LH, Bianchi $\mathrm{E}$, et al. Identification of amino acid residues in CD81 critical for interaction with hepatitis C virus envelope glycoprotein E2.J Vi rol. 2000;74(8):3642-9.

7. Scarselli E, Ansuini H, Cerino R, Roccasecca RM, Acali S, Filocamo G, et al. The human scavenger receptor class B type I is a novel candidate receptor for the hepatitis $\mathrm{C}$ virus. EMBO J. 2002;21(19):5017-25.

8. Ashfaq UA, Qasim M, Yousaf MZ, Awan MT, Jahan S. Inhibition of HCV 3a genotype entry through host CD81 and HCV E2 antibodies. JTransl Med. 2011;9:194.

9. Brown RJ, Tarr AW, McClure CP, Juttla VS, Tagiuri N, Irving WL, et al. Cross-genotype characterization of genetic diversity and molecular adaptation in hepatitis $C$ virus envelope glycoprotein genes. J Gen Virol. 2007;88(Pt 2):458-69.

10. Slater-Handshy T, Droll DA, Fan X, Di Bisceglie AM, Chambers TJ. HCV E2 glycoprotein: mutagenesis of N-linked glycosylation sites and its effects on E2 expression and processing. Virology. 2004;319(1):36-48

11. Pileri P, Uematsu Y, Campagnoli S, Galli G, Falugi F, Petracca $\mathrm{R}$, et al. Binding of hepatitis $\mathrm{C}$ virus to CD81. Science. 1998;282(5390):938-41.

12. Helle F, Dubuisson J. Hepatitis C virus entry into host cells. Cell Mol Life Sci. 2008;65(1):100-12.

13. Schonning K, Jansson B, Olofsson S, Hansen JE. Rapid selection for an N-linked oligosaccharide by monoclonal antibodies directed against the V3 loop of human immunodeficiency virus type 1.J Gen Virol. 1996;77 ( Pt 4):753-8.

14. Wei X, Decker JM, Wang S, Hui H, Kappes JC, Wu X, et al. Antibody neutralization and escape by HIV-1. Nature. 2003;422(6929):30712 .

15. Bugli F, Mancini N, Kang CY, Di Campli C, Grieco A, Manzin A, et al. Mapping B-cell epitopes of hepatitis C virus E2 glycoprotein using human monoclonal antibodies from phage display libraries. JVirol. 2001;75(20):9986-90.

16. Giang E, Dorner M, Prentoe JC, Dreux M, Evans MJ, Bukh J, et al Human broadly neutralizing antibodies to the envelope glycoprotein complex of hepatitis C virus. Proc Natl Acad Sci U S A. 2012;109(16):6205-10.

17. Fournillier A, Wychowski C, Boucreux D, Baumert TF, Meunier JC, Jacobs D, et al. Induction of hepatitis $\mathrm{C}$ virus E1 envelope proteinspecific immune response can be enhanced by mutation of $\mathrm{N}$ glycosylation sites. JVirol. 2001;75(24):12088-97.

18. El-Awady MK, Tabll AA, Atef K, Yousef SS, Omran MH, El-Abd Y, et al. Antibody to E1 peptide of hepatitis $C$ virus genotype 4 inhibits virus binding and entry to HepG2 cells in vitro. World J Gastroen- terol. 2006;12(16):2530-5.

19. El-Awady MK, Tabll AA, El-Abd YS, Yousif H, Hegab M, Reda M, et al Conserved peptides within the $\mathrm{E} 2$ region of Hepatitis $\mathrm{C}$ virus induce humoral and cellular responses in goats. Virol J. 2009;6:66.

20. Baldick CJ, Wichroski MJ, Pendri A, Walsh AW, Fang J, Mazzucco $\mathrm{CE}$, et al. A novel small molecule inhibitor of hepatitis $C$ virus entry. PLoS Pathog. 2010;6(9).

21. Dorner M, Horwitz JA, Robbins JB, Barry WT, Feng Q, Mu K, et al. A genetically humanized mouse model for hepatitis $C$ virus infection. Nature. 2011;474(7350):208-11.

22. Sainz BJ, Barretto N, Martin DN, Hiraga N, Imamura M, Hussain $\mathrm{S}$, et al. Identification of the Niemann-Pick C1-like 1 cholestero absorption receptor as a new hepatitis $\mathrm{C}$ virus entry factor. Nat Med. 2012;18(2):281-5

23. Mittapalli GK, Zhao F, Jackson A, Gao H, Lee H, Chow S, et al. Discovery of ITX 4520: a highly potent orally bioavailable hepatitis C virus entry in hibitor. Bioorg Med Chem Lett. 2012;22(15):4955-61.

24. Zhu H, Wong-Staal F, Lee H, Syder A, McKelvy J, Schooley RT, et al. Evaluation of ITX 5061, a scavenger receptor B1 antagonist: resistance selection and activity in combination with other hepatitis C virus antivirals. J Infect Dis. 2012;205(4):656-62.

25. Gededzha MP, Selabe SG, Kyaw T, Rakgole JN, Blackard JT Mphahlele MI. Introduction of new subtypes and variants of hepatitis C virus genotype 4 in South Africa. J Med Virol. 2012;84(4):601-7.

26. Gededzha MP, Selabe SG, Blackard JT, Kyaw T, Mphahlele MJ. Near full-length genome analysis of HCV genotype 5 strains from South Africa. Infect Genet Evol. 2014;21:118-23.

27. Koletzki D, Dumont S, Vermeiren H, Peixe P, Nina J, Camacho RJ, et al. Full genome sequence of three isolates of hepatitis $\mathrm{C}$ virus subtype 4b from Portugal. Arch Virol. 2009;154(1):127-32.

28. Gasteiger E, Hoogland C, Gattiker A, Duvaud S, Wilkins MR, Appel RD. Protein Identification and Analysis Tools on the ExPASy Server. In: Walker JM editor. The Proteomics Protocols Handbook. Humana Press; 2005. pp. 571-607.

29. Saha S, Raghava GP. Prediction of continuous B-cell epitopes in an antigen using recurrent neural network. Proteins. 2006;65(1):40-8

30. Blom N, Gammeltoft S, Brunak S. Sequence and structure-based prediction of eukaryotic protein phosphorylation sites. J Mo Biol.1999;294(5):1351-62.

31. Penin F, Dubuisson J, Rey FA, Moradpour D, Pawlotsky JM. Structural biology of hepatitis C virus. Hepatology. 2004;39(1):5-19

32. Genovese D, Dettori S, Argentini C, Villano U, Chionne P, Angelico $\mathrm{M}$, et al. Molecular epidemiology of hepatitis $\mathrm{C}$ virus genotype 4 isolates in Egypt and analysis of the variability of envelope proteins E1 and E2 in patients with chronic hepatitis. J Clin Microbiol. 2005;43(4):1902-9.

33. Zhang P, Zhong L, Struble EB, Watanabe H, Kachko A, Mihalik K, et al. Depletion of interfering antibodies in chronic hepatitis $\mathrm{C}$ patients and vaccinated chimpanzees reveals broad cross-genotype neutralizing activity. Proc Natl Acad Sci USA. 2009;106(18):7537-41

34. Tarr AW, Urbanowicz RA, Jayaraj D, Brown RJ, McKeating JA, Ir ving $\mathrm{WL}$, et al. Naturally occurring antibodies that recognize linear epitopes in the amino terminus of the hepatitis $C$ virus E2 protein confer noninterfering, additive neutralization. J Virol. 2012;86(5):2739-49.

35. Manzin A, Solforosi L, Petrelli E, Macarri G, Tosone G, Piazza M et al. Evolution of hypervariable region 1 of hepatitis $C$ virus in primary infection. J Virol.1998;72(7):6271-6.

36. Farci P, Alter HJ, Wong DC, Miller RH, Govindarajan S, Engle R, et al. Prevention of hepatitis $C$ virus infection in chimpanzees after antibody-mediated in vitro neutralization. Proc Natl Acad Sci U S A. 1994;91(16):7792-6.

37. Ikram A, Anjum S, Tahir M. In Silico Identification and Conservation Analysis of B-cell and T-Cell Epitopes of Hepatitis C Virus 3a Genotype Enveloped Glycoprotein 2 From Pakistan: A Step Towards Heterologous Vaccine Design. Hepat Mon. 2014;14(6).

38. Yusim K, Kesmir C, Gaschen B, Addo MM, Altfeld M, Brunak S, et al. Clustering patterns of cytotoxic T-lymphocyte epitopes in human immunodeficiency virus type 1 (HIV-1) proteins revea imprints of immune evasion on HIV-1 global variation. J Virol. 2002;76(17):8757-68. 


\section{Gededzha MP et al.}

39. Greenberg ML, Cammack N. Resistance to enfuvirtide, the first HIV fusion inhibitor. J Antimicrob Chemother. 2004;54(2):333-40.

40. Hrobowski YM, Garry RF, Michael SF. Peptide inhibitors of dengue virus and West Nile virus infectivity. Virol J. 2005;2:49.

41. Bai F, Town T, Pradhan D, Cox J, Ledizet M, Ashish., et al. Antivira peptides targeting the west nile virus envelope protein. J Virol. 2007;81(4):2047-55.

42. Liu R, Tewari M, Kong R, Zhang R, Ingravallo P, Ralston R. A pep- tide derived from hepatitis $\mathrm{C}$ virus E2 envelope protein inhibits a post-binding step in HCV entry. Antiviral Res. 2010;86(2):172-9.

43. Wang G. Post-translational Modifications of Natural Antimicrobial Peptides and Strategies for Peptide Engineering. Curr Biotechnol. 2012;1(1):72-9.

44. Beyene A, Basu A, Meyer K, Ray R. Hepatitis C virus envelope glycoproteins and potential for vaccine development. Vox Sang. 2002;83 Suppl 1:27-32. 